\title{
PURIFICATION OF INDONESIAN NATURAL GRAPHITE AS CANDIDATE FOR NUCLEAR FUEL MATRIX BY ACID LEACHING METHOD: CHEMICAL CHARACTERIZATION
}

\author{
Deni Mustika ${ }^{1}$, Torowati ${ }^{1}$, Arbi Dimyati ${ }^{2}$, Sudirman ${ }^{2}$, Adel Fisli $^{2}$, \\ I Made Joni ${ }^{3}$, Ratih Langenati ${ }^{1}$ \\ ${ }^{1}$ Center for Nuclear Fuel Technology - BATAN \\ PUSPIPTEK AREA, Setu, South Tangerang, Banten, Indonesia, 15346 \\ ${ }^{2}$ Center for Science and Technology of Advanced Materials - BATAN \\ PUSPIPTEK AREA, Setu, South Tangerang, Banten, 15346 \\ ${ }^{3}$ Nanotechnology and Graphene Research Center (NGRC), Directorate of Research and \\ Community Development - Padjadjaran University \\ Jl. Raya Bandung - Sumedang Km 21, Jatinangor, Sumedang, West Java, Indonesia, 45363 \\ e-mail:dmustika@batan.go.id \\ (Naskah diterima: 15-9-2020, Naskah direvisi: 7-10-2020, Naskah disetujui: 21-10-2020)
}

\begin{abstract}
PURIFICATION OF INDONESIAN NATURAL GRAPHITE AS CANDIDATE FOR NUCLEAR FUEL MATRIX BY ACID LEACHING METHOD: CHEMICAL CHARACTERIZATION. Graphite matrix in Pebble Bed Reactor (PBR) - High Temperature Gas Cooled Reactor (HTGR) has an important role as heat transfer medium, neutron moderator and structural material to protect fuel. Thus, graphite matrix must fulfill chemical and physical characteristics for PBR-HTGR fuel. Indonesia has graphite sources in several regions that can potentially be purified. This research aimed to purify Indonesian natural graphite by several variation of acids and to perform chemical characterizations. Natural graphite from flotation process was purified by several variations of acid, i. e., hydrofluoric acid (HF), sulphuric acid + nitric acid $\left(\mathrm{H}_{2} \mathrm{SO}_{4}+\mathrm{HNO}_{3}\right)$ and hydrofluoric acid + hydrochloric acid + sulphuric acid $\left(\mathrm{HF}+\mathrm{HCl}+\mathrm{H}_{2} \mathrm{SO}_{4}\right)$ and subsequently followed by chemical characterizations such as purity level, ash content, and boron quivalent. The highest purity was obtained in the purification process by HF with carbon content up to $99.52 \%$; this purity level fulfills the specification of nuclear graphite (>99\%). Ash content analysis shows a value in compliance with the specification requirement, i.e., $<100 \mathrm{ppm}$, and boron equivalent value also fulfills the specification value of $<1 \mathrm{ppm}$. It can be concluded from this study that the graphite purified by acid leaching with HF can be used as fuel matrix candidate but is qualified as low quality. Futher research is required to produce high quality nuclear graphite, particularly research in the minimization of the impurity by evaporation at temperatures over $950{ }^{\circ} \mathrm{C}$ to by far lower the ash content.
\end{abstract}

Keywords: Indonesian natural graphite, purification, nuclear fuel matrix, acid leaching, chemical characterization. 


\begin{abstract}
ABSTRAK
PEMURNIAN GRAFIT ALAM INDONESIA SEBAGAI MATRIKS BAHAN BAKAR NUKLIR DENGAN METODE ACID LEACHING: KARAKTERISASI KIMIA. Matriks grafit dalam Pebble Bed Reactor (PBR) - High Temperature Gas Cooled Reactor (HTGR) memiliki peran penting, tidak hanya sebagai moderator netron dan material struktur untuk melindungi bahan bakar, namun juga sebagai media transfer panas. Oleh karena grafit matriks harus memenuhi karakteristik kimia dan fiskia untuk bahan bakar PBR - HTGR. Penelitian ini bertujuan untuk memurnikan grafit alam Indonesia dengan beberapa variasi asam dan melakukan karakterisasi kimia sebagai kandidat matriks bahan bakar nuklir PBR - HTGR. Grafit alam hasil flotasi dimurnikan dengan berbagai variasi asam yaitu asam fluorida (HF), asam sulfat + asam nitrat $\left(\mathrm{H}_{2} \mathrm{SO}_{4}+\mathrm{HNO}_{3}\right)$ dan asam fluorida + asam klorida + asam sulfat $\left(\mathrm{HF}+\mathrm{HCl}+\mathrm{H}_{2} \mathrm{SO}_{4}\right)$, selanjutnya dilakukan karakterisasi kimia berupa kemurnian, kadar abu, impuritas dan boron ekuivalen sebagai kandidat matriks bahan bakar nuklir. Pemurnian menghasilkan grafit dengan kemurnian tertinggi pada pemurnian dengan $\mathrm{HF}$, diperoleh kadar karbon hingga 99,52\% memenuhi spesifikasi grafit nuklir (>99\%). Kadar abu belum memenuhi persyaratan yaitu < 100 ppm, namun untuk Boron ekuivalen memenuhi spesifikasi yaitu $<1$ ppm. Dari studi ini dapat disimpulkan bahwa grafit hasil pemurnian dengan metode acid leaching HF dapat digunakan sebagai kandidat bahan bakar dengan kualitas rendah. Untuk menghasilkan grafit nuklir kualitas tinggi perlu dilakukan studi lebih lanjut terutama meminimalisir impuritas yang memiliki suhu penguapan diatas $950^{\circ} \mathrm{C}$ sehingga dapat menurunkan kadar abu pada grafit.
\end{abstract}

Kata kunci: Grafit alam indonesia, pemurnian, matriks bahan bakar nuklir, acid leaching, karakterisasi kimia 


\section{INTRODUCTION}

High Temperature Gas Cooled Reactor (HTGR)-Pebble Bed Reactor (PBR) type is a potential candidate for generation IV power reactor with the following characteristics: high safety level, high thermal efficiency, economically competitive, and flexible application. During accidents, this reactor can perform natural cooling without external support due to passive safety feature. Radioactive releases produced into the environment is very low even during accidents. Application flexibility is gained from high temperature steam output which can be used by industries requiring heat such as gasification and melting of coal, melting process, water desalination, and hydrogen production [1-3].

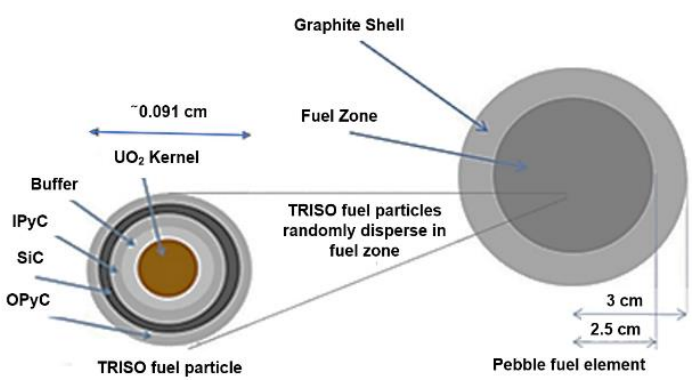

Fig. 1. PBR type HTGR fuel in the form of dispersed kernel in sphericle fuel element [4]

PBR-HTGR is round shaped fuel with $60 \mathrm{~mm}$ in diameter consists of $50 \mathrm{~mm}$ diameter of fuel zone and $5 \mathrm{~mm}$ thickness of fuel-free zone [4]. Fuel particle is composed of uranium oxide kernel coated by carbide and layered with pyrolytic carbon dispersed in graphite matrix (Figure 1). Graphite matrix acts as neutron moderator, fuel protection material structure, and heat transfer medium and thus needs suitable physical and chemical properties [1]. Graphite matrix is formulated by mixing natural graphite, synthetic graphice, and phenolic resin binder. One of graphite matrix type is A3-3 matrix which consists of $64 \%$ natural graphite, $16 \%$ synthetic graphite and $20 \%$ phenolic resin binder which processed by mixing, drying and milling $[1,3]$. The characteristics of nuclear level natural graphite are having purity of more than $99 \%$, ash content around $100 \mathrm{ppm}$, lithium content less than $0,005 \mathrm{ppm}$ and boron equivalent less than $1 \mathrm{ppm}$. Impurity in graphite lower the corrosion resistance and other performance such as thermal conductivity, mechanical power, and irradiation performance inside the reactor [1, 2, 5, 6-8].

Graphite is natural mineral with carbon composition in hexagonal crystal system and density of $2.23 \mathrm{~g} / \mathrm{cc}[9,10]$. Natural graphite is very anisotropy but can be milled to produce fine powder and reshaped into macro isotropy graphite [1].

Indonesian natural graphite is found in Sumatera, Sulawesi, and Kalimantan with the highest content found in Sanggau regency, West Kalimantan [9-11] with the prospect for purification using various method-among them flotation [11,12] and acid leaching $[13,14]$. Based on the need of natural graphite as nuclear fuel matrix and Indonesia's potential natural graphite, further research on Indonesian natural graphite purification is required to fulfill the specification of nuclear fuel matrix.

Initial natural graphite separation and purification method generally utilize the difference of chemical and physical properties between phases, known as flotation method [11]. Graphite naturally float in water because it is hydrophobic. Several reagents are added to increase recovery [12]. Graphite with higher concentration is further purified by hydrometallurgy and pyrometallurgy used for various application [15-18]. Hydrometallurgy purification with acid leaching is often chosen because it is simple, effective, and economical. The use of acid mixture has the advantage of eliminating impurities existing within the crevices of graphite crystal [19]. Wei Xie improves the concentration of natural graphite microcrystal in China by using hydrochloric acid 
and sodium fluoride up to $98.37 \%$ [18], $\mathrm{K}$. Zhagib purified Brazilian natural graphite by $\mathrm{H}_{2} \mathrm{SO}_{4}$ and $\mathrm{NH}_{x} \mathrm{~F}_{y}$ to produce graphite with $98.5 \%$ purity [15]. Li Yu-Feng used $\mathrm{HCl} / \mathrm{HNO}_{3}$ and produced graphite with carbon content up to $95.84 \%$ and with the help of microwave higher carbon content of $98.57 \%$ was obtained [19], however application of heat can influence graphite crystalline properties. Panatarani improved the concentration of natural graphite by using hydrofluoric acid up to $92.36 \%$ [13]. Zhou, Tang and Zhao reported that they obtained natural graphite with purity up to $99 \%$ using hydrofluoric acid + hydrochloric acid + sulphuric acid $(\mathrm{HF}+\mathrm{HCl}+\mathrm{H} 2 \mathrm{SO} 4)[2,5,6]$. The choice of acid type determines the purity level of graphite produced.

This research aimed to purify Indonesian natural graphite with several acid variation and to conduct chemical characterization as PBR - HTGR nuclear fuel matrix candidate.

In this research, the natural graphite which was previously processed by flotation was the purified by several acid variations which were $\mathrm{HF}$ [13], $\mathrm{H}_{2} \mathrm{SO}_{4}+\mathrm{HNO}_{3}$ [20], $\mathrm{HF}+\mathrm{HCl}+\mathrm{H}_{2} \mathrm{SO}_{4} \quad[5,6]$, and chemical characterization was performed to measure impurity, ash content [21], impurity and boron equivalent [22] as nuclear fuel matrix candidate.

\section{METHODS}

The natural graphite material used in this work was obtained from Sanggau Regency, West Kalimantan which has undergone milling and flotation process. The chemical compound used is hydrofluoric acid, sulphuric acid, hydrochloric acid, and nitric acid, all pro-analysis materials from Merck. This research utilized acetylene, nitrous oxide, helium, and argon gasses in ultra high purity (UHP). Distilled water was produced from DIRECT-Q 3 UV-R SYSTEM.

Purification method in this research was acid leaching with a variety of acids which were hydrofluoric acid, sulphuric acid + nitric acid $\left(\mathrm{H}_{2} \mathrm{SO}_{4}+\mathrm{HNO}_{3}\right)$ with a ratio of $1: 1$, hydrofluoric acid + hydrochloric acid + sulphuric acid $\left(\mathrm{HF}+\mathrm{HCl}+\mathrm{H}_{2} \mathrm{SO}_{4}\right)$ with a ratio of $1: 1: 1$. The weight ratio of graphite and acid was 1:5. The ingredients were mixed by magnetic stirrer and later separated by centrifuge. Graphite was washed several times until neutral and then filtered by filter paper until acid free graphite was obtained. Graphite was further dried in the oven and crushed. Graphite powder from purification was then ready for characterization.

Carbon level was determined by SEM/EDS Jeol 6510LA using ZAF method standarless quantitatives analysis dan Carbon and Sulphur Analyzer, (CS 744 LECO with mass reduction modification). Ash content was determined by Loss on Ignition method in $\pm 950^{\circ} \mathrm{C}$ temperature. Impurity and boron equivalent used Neutron Activation Analysis (NAA), Flame-Atomic Absorption Spectrophotometer (F-AAS Agilent) and Inductively Coupled Plasma-Optical Emission Spectrometer (ICP-OES Perkin Elmer). Measurement with NAA, sample was analyzed without treatment while for AAS and ICP-OES, graphite impurity was previously washed with $\mathrm{HNO}_{3}$ and $\mathrm{H}_{2} \mathrm{SO}_{4}$ mixture with the help microwave.

\section{RESULTS AND DISCUSSIONS}

\section{Carbon Content Analysis by EDS and CS Analyzer}

Spectrum of graphite content measurement before and after purification by SEM-EDS is shown in Figure 2. The carbon level of natural graphite pre-purification, post purification with $\mathrm{HF}$, purification with $\mathrm{H}_{2} \mathrm{SO}_{4}+\mathrm{HNO}_{3}$ and purification with $\mathrm{HF}+\mathrm{HCl}_{+} \mathrm{H}_{2} \mathrm{SO}_{4}$ using SEM-EDS with ZAF methods standardless qualitative analysis obtained the following results, respectively: $89.68 \%$, 99.52\%, 93.98\% and $96.21 \%$ with each fitting coefficient being $0.1994 ; 0.4178$; 0.3976 and 0.4400 . The highest increase of graphite mass percentage was obtained in purification by hydrofluoric acid and fulfilled the characteristic for nuclear grade natural graphite characteristics [1, 2, 5, 6-8]. 
Graphite mass percentage pre and post purification with HF obtained the highest value compared to the result obtained by Panatarani which was 76.502 compared to $92.36 \%$ [13], This is because pre-purification graphite used has higher percentage $(89.68 \%)$ and the difference of used graphite particle size distribution. The higher the purity of the graphite pre-purification then the impurity soluted by acid leaching will be fewer and will produce graphite with higher purity. Distribution of graphite particle size influence the powder's surface area which reacted with acid during acid leaching.

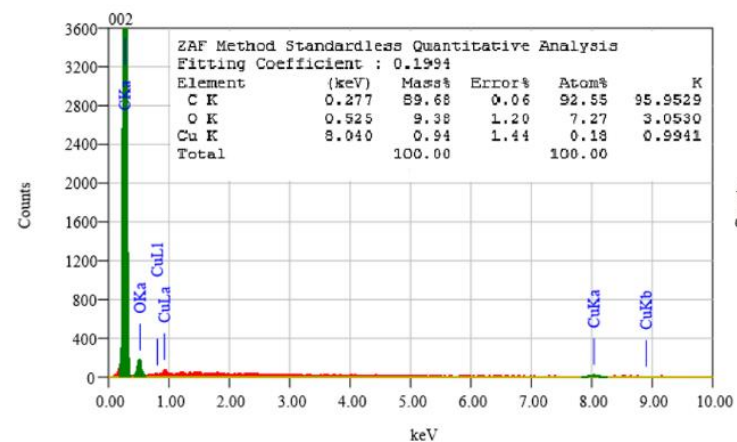

(a)

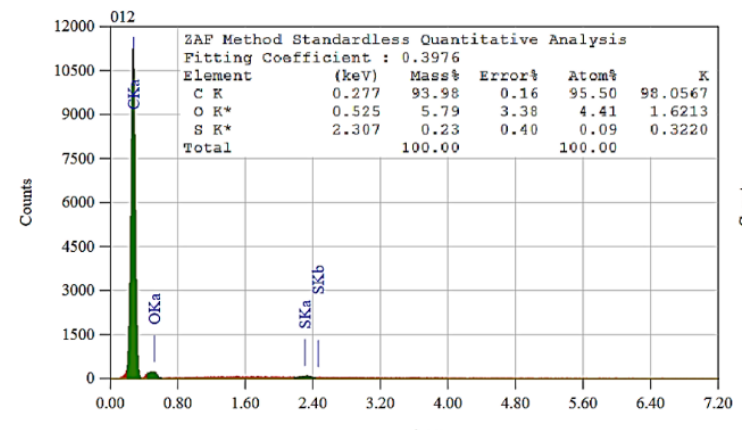

(c)

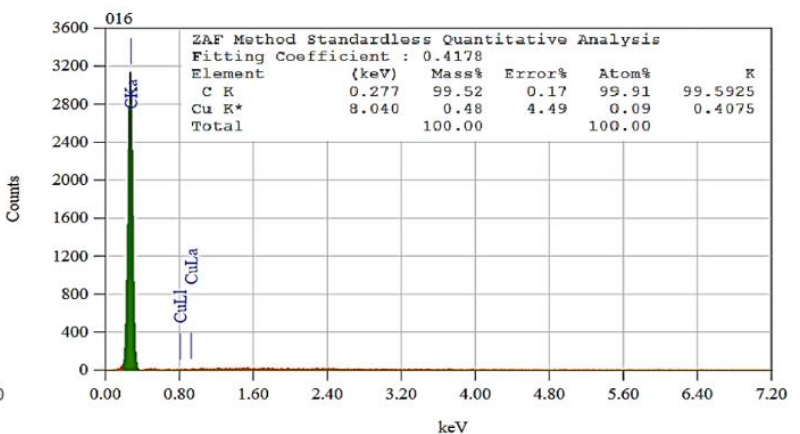

(b)

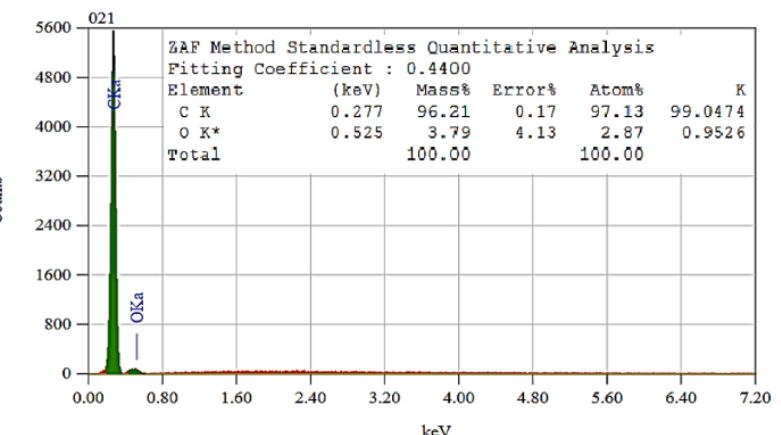

(d)

Fig. 2. EDS graphite spectrum
a. pre-purification
b. post $\mathrm{HF}$ purification
c. post $\mathrm{H}_{2} \mathrm{SO}_{4}+\mathrm{HNO}_{3}$ purification
d. post $\mathrm{HF}+\mathrm{HCl}+\mathrm{H}_{2} \mathrm{SO}_{4}$ purification.

Carbon Sulphur Analyzer was used to determine the carbon content with other method, which are based on infrared energy (IR) by sulphur oxide $\left(\mathrm{SO}_{2}\right)$ and carbon dioxide $\left(\mathrm{CO}_{2}\right)$ produced from burning/sample oxidation by pure oxygen [23], and by reducing the mass, the carbon level of graphite before and after purification can be observe in Figure 3. The carbon level pre and post purification with $\mathrm{HF}$, purification with
$\mathrm{H}_{2} \mathrm{SO}_{4}+\mathrm{HNO}_{3}$ and purification by $\mathrm{HF}+\mathrm{HCl}+\mathrm{H}_{2} \mathrm{SO}_{4}$ respectively each obtained $89.60 \pm 1.50 \%, \quad 99.20 \pm 0.35 \%, \quad 94.26 \pm 0.39 \%$ and $97.5 \pm 1.36 \%$. The highest carbon rate was obtained from HF purification with $99.20 \%$, which fulfilled the characteristics of nuclear grade natural graphite [1, 2, 5, 6-8], This is in line with what was obtained by EDS in Figure 2. 


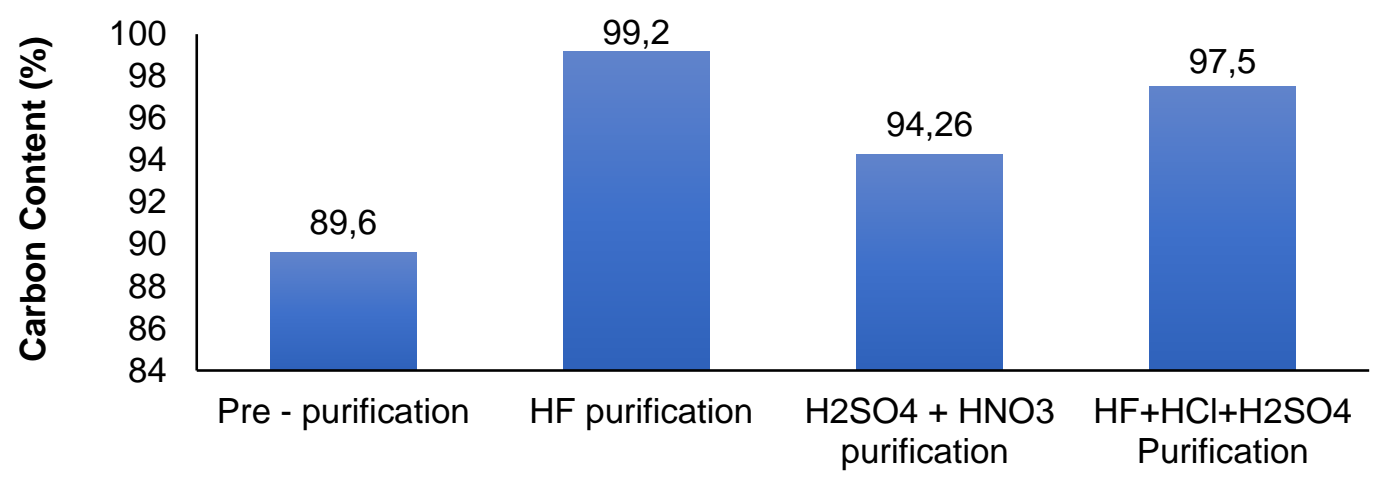

Fig. 3. Graphite carbon level pre and post acid purification by using carbon sulphur analyzer

\section{Ash Content Analysis}

Ash content analysis in graphite post and pre acid leaching purification is shown in Figure 3. Ash content for graphite pre and post purification with acid leaching, post purification with $\mathrm{HF}$, purification $\mathrm{H}_{2} \mathrm{SO}_{4}+\mathrm{HNO}_{3}$ and purification with $\mathrm{HF}+\mathrm{HCl}+\mathrm{H}_{2} \mathrm{SO}_{4}$ respectively obtained 9.587 , $0.796,1.781$ and $1.054 \%$. The lowest ash content was obtained in purification with $\mathrm{HF}$ followed by graphite purification with
$\mathrm{HF}+\mathrm{HCl}_{+} \mathrm{H}_{2} \mathrm{SO}_{4}$ and $\mathrm{H}_{2} \mathrm{SO}_{4}+\mathrm{HNO}_{3}$. This is in accordance with EDS and Carbon Sulphur Analyzer result. However, if compared with nuclear grade natural graphite characteristics, the ash content in graphite from this acid is still higher [1, 2, 5, 6-8]. Ash content in sample showed the amount of ingredients that did not disappear in a sample under $950^{\circ} \mathrm{C}$ temperature and can be used as an indicatior of a materials' purity properties.

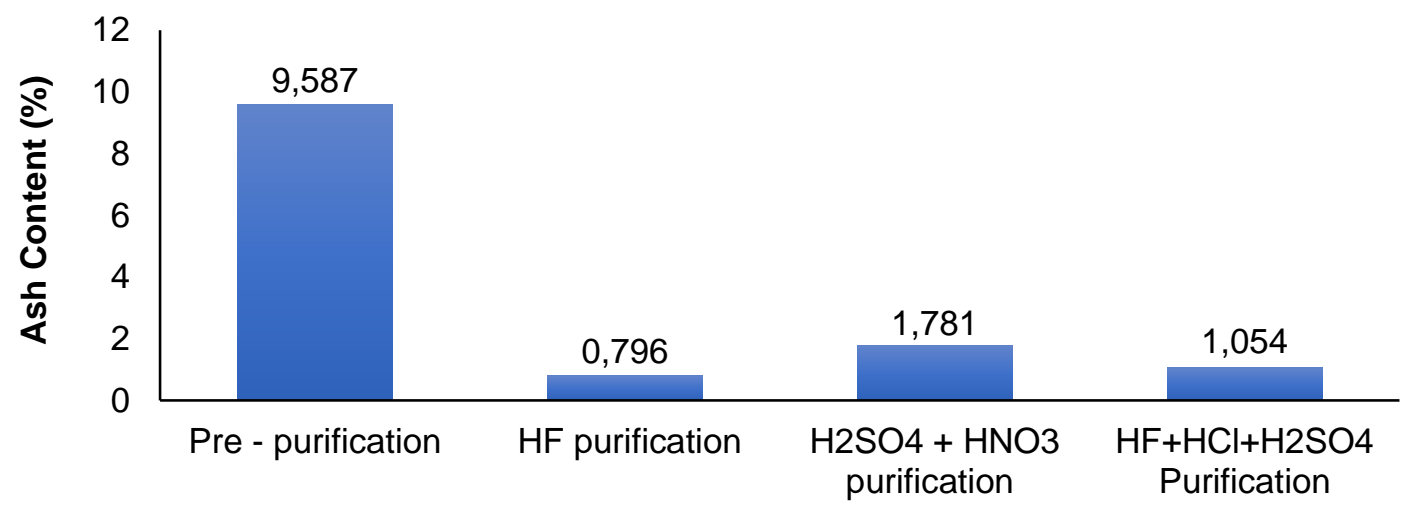

Fig. 3. Graphite ash content pre and post acid leaching purification

\section{Impurity and Boron Equivalent Analysis}

Assessment of graphite impurity was performed with two methods, non-destructive test by neutron activation analysis (NAA) (AAN) and destructive test by AAS and ICP-OES. Table 1 displayed the result of impurity assessment pre and post acid leaching purification.

From Table 1 it can be observed that total graphite impurity pre and post purification obtained by NAA, AAS and
ICP-OES, each result respectively obtained $94246.66 \mu \mathrm{g} / \mathrm{g}, 2684.73 \mu \mathrm{g} / \mathrm{g}, 6888.78 \mu \mathrm{g} / \mathrm{g}$ and $5139.75 \mu \mathrm{g} / \mathrm{g}$. The lowest impurity was obtained in graphite with HF purification. This is in accordance with EDS, CS analyzer and ash content analysis.

Other impurities that should be avoided in graphite matrix are elements that contributed in neutron absorption. Neutron absorption rate from certain impurity can be called as Equivalent Boron Content-EBC as shown in equation 1 [21]. 


$$
E B C_{\text {Total }}=\sum\left(\frac{E B C \text { Factor }}{\text { Impurity content }\left({ }^{\mu g} / g\right)}\right)(1)
$$

In determining EBC, B, Dy, Eu, Gd, Sm, Li and $\mathrm{Cd}$ impurity should be known for each being $1.000 ; 0.0818 ; 0.4250 ; 4.3991 ; 0.5336$; 0.4139 and 0.3172 , respectively. Other than the about 7 elements, EBC factor element was 0.0001 to 0.0263 with relatively low contribution in neutron absorption [21]. In Table 1, B, Dy, Eu, Gd, Sm, Li and Cd content showed that pre-purification graphite had Dy with $24540 \mu \mathrm{g} / \mathrm{g}$ concentration and sample post purification with $\mathrm{H}_{2} \mathrm{SO}_{4}+\mathrm{HNO}_{3}$ contained B $156.63 \mu \mathrm{g} / \mathrm{g}$. In other analysis, limit was not detected in B, Dy, Eu, Gd, Sm, Li and Cd with each being $0.44 \mu \mathrm{g} / \mathrm{g}, 0.09 \mu \mathrm{g} / \mathrm{g}, 0.03 \mu \mathrm{g} / \mathrm{g}$, $0.03 \mu \mathrm{g} / \mathrm{g}, 0.03 \mu \mathrm{g} / \mathrm{g}, 0.01 \mu \mathrm{g} / \mathrm{g}$ and $0.05 \mu \mathrm{g} / \mathrm{g}$. Equivalent Boron Content in graphite pre and post purification with $\mathrm{H}_{2} \mathrm{SO}_{4}+\mathrm{HNO}_{3}$ was higher compared to nuclear graphite sized $<1 \mu \mathrm{g} / \mathrm{g}$, while graphite from purification with $\mathrm{HF}$ and $\mathrm{HF}+\mathrm{HCl}+\mathrm{H}_{2} \mathrm{SO}_{4}$ fulfilled the Equivalent Boron Content requirements for nuclear graphite [1, 2, 5, 6-8].

Table 1. Graphite impurity data pre and post acid leaching purification

\begin{tabular}{|c|c|c|c|c|c|}
\hline \multirow{2}{*}{ Element } & \multicolumn{4}{|c|}{ Content Impurities $(\mu \mathrm{g} / \mathrm{g})$} & \multirow{2}{*}{ Method } \\
\hline & Pre & $\mathrm{HF}$ & $\mathrm{H}_{2} \mathrm{SO}_{4}+\mathrm{HNO}_{3}$ & $\mathrm{HF}+\mathrm{HCl}_{+} \mathrm{H}_{2} \mathrm{SO}_{4}$ & \\
\hline $\mathrm{Al}$ & $741 \pm 45$ & $725 \pm 40$ & $696 \pm 17$ & $593 \pm 15$ & $\mathrm{AAN}^{*}$ \\
\hline $\mathrm{B}$ & $<0.44$ & $<0.44$ & $156.63 \pm 0.04$ & $<0.44$ & ICP \\
\hline $\mathrm{Cd}$ & $<0.05$ & $<0.05$ & $<0.05$ & $<0.05$ & ICP \\
\hline Co & $5.59 \pm 0.47$ & $1.49 \pm 0.06$ & $4.13 \pm 0.2$ & $4.09 \pm 0.32$ & $\mathrm{AAN}^{*}$ \\
\hline $\mathrm{Cr}$ & $74.80 \pm 0,14$ & $46.41 \pm 0.01$ & $54.62 \pm 0.01$ & $51.05 \pm 0.01$ & AAS \\
\hline $\mathrm{Cu}$ & $60,675 \pm 2.14$ & $1,088 \pm 59$ & $925 \pm 58$ & $835 \pm 57$ & $\mathrm{AAN}^{*}$ \\
\hline Dy & 24,540 & $<0.09$ & $<0.09$ & $<0.09$ & ICP \\
\hline Eu & $<0.03$ & $<0.03$ & $<0.03$ & $<0.03$ & $\mathrm{ICP}$ \\
\hline $\mathrm{Fe}$ & $1379.20 \pm 80,00$ & $216.47 \pm 0.01$ & $153.21 \pm 0.01$ & $580.13 \pm 0.01$ & AAS \\
\hline $\mathrm{Gd}$ & $<0.03$ & $<0.03$ & $<0.03$ & $<0.03$ & ICP \\
\hline $\mathrm{K}$ & $163.70 \pm 0.01$ & $21.65 \pm 0.01$ & $71.48 \pm 0.01$ & $21.58 \pm 0.01$ & AAS \\
\hline $\mathrm{La}$ & $3.56 \pm 0,33$ & $3.09 \pm 0.16$ & $2.15 \pm 0.14$ & $2.27 \pm 0.16$ & $\mathrm{AAN}^{*}$ \\
\hline $\mathrm{Li}$ & < LD 0.01 & < LD 0.01 & < LD 0.01 & $<$ LD 0.01 & AAS \\
\hline $\mathrm{Mg}$ & $253.40 \pm 4,60$ & $27.20 \pm 1.99$ & $175.70 \pm 8.99$ & $15.76 \pm 0.33$ & AAS \\
\hline $\mathrm{Mn}$ & $9.04 \pm 0.38$ & $2.05 \pm 0.07$ & $2.7 \pm 0.07$ & $1.87 \pm 0.08$ & $\mathrm{AAN}^{*}$ \\
\hline $\mathrm{Na}$ & $171 \pm 10.6$ & $170 \pm 8.8$ & $39.2 \pm 1.3$ & $29.4 \pm 1.19$ & $\mathrm{AAN}^{*}$ \\
\hline $\mathrm{Ni}$ & $70.60 \pm 0,24$ & $21.73 \pm 0.002$ & $31.79 \pm 0.02$ & $<0.02$ & AAS \\
\hline $\mathrm{Pb}$ & $190 \pm 0,18$ & $221.398 \pm 0.075$ & $200.03 \pm 0.01$ & $143.16 \pm 0.05$ & AAS \\
\hline $\mathrm{Sb}$ & $5,514 \pm 14$ & $93 \pm 2,4$ & $4,348 \pm 49$ & $3,421 \pm 37$ & $\mathrm{AAN}^{*}$ \\
\hline Sc & $0.28 \pm 0.03$ & $0.14 \pm 0.01$ & nd & nd & $\mathrm{AAN}^{*}$ \\
\hline Sm & $<0.03$ & $<0.03$ & $<0.03$ & $<0.03$ & ICP \\
\hline V & $27.5 \pm 1.26$ & $15.09 \pm 0.54$ & $9.1 \pm 0.31$ & $14.6 \pm 0.51$ & $\mathrm{AAN}^{*}$ \\
\hline W & $19.4 \pm 1.67$ & $16.59 \pm 0.63$ & $18.8 \pm 0.74$ & $19.14 \pm 0.78$ & $\mathrm{AAN}^{*}$ \\
\hline $\mathrm{Zn}$ & $408 \pm 34.7$ & $14.74 \pm 1.02$ & nd & nd & $\mathrm{AAN}^{*}$ \\
\hline Sum & $94,246.66$ & $2,684.73$ & $6,888.78$ & $5,139.75$ & \\
\hline
\end{tabular}
*[24] 


\section{CONCLUSION}

Natural graphite purification with acid variations which were hydrofluoric acid (HF), sulphuric acid + nitric acid $\left(\mathrm{H}_{2} \mathrm{SO}_{4}+\mathrm{HNO}_{3}\right)$ and hydrofluoric acid + hydrochloric acid + sulphuric acid $\left(\mathrm{HF}+\mathrm{HCl}+\mathrm{H}_{2} \mathrm{SO}_{4}\right)$ as a candidate for nuclear fuel matrix produced graphite with highest purity in purification with $\mathrm{HF}$, and the carbon level found was up to $99.52 \%$ which fulfill the requirements for nuclear graphite $(>99 \%)$. Ash content was still below requirements which was $<100$ ppm. However, for boron equivalent the value obtained fulfilled the specification intended which was $<1 \mathrm{ppm}$. From this study it can be concluded that graphite obtained from purification with acid leaching HF method can be used as low quality fuel candidate. To produce high quality graphite, further study should be conducted, especially to minimized impurities with evaporation temperature being over $950{ }^{\circ} \mathrm{C}$ which can lower the ash level of graphite.

\section{ACKNOWLEDGEMENT}

Writer would like to express gratitude to Ministry of Research and Higher Education which has funded this research in Insinas Flagship program, Ibu. Dr. Geni Rina Sunaryo, M.Sc, Bapak Ir. Agus Sumaryanto, M.S.M and Prof, Ridwan who had facilitated the research. Comrades in UNPAD, PSTBM, PTBBN dan PTBGN who had helped a lot during this research. Special thanks we expressed to The Late Mrs Lilis Windaryati who had supported and left great memories during the course of this research.

\section{REFERENCES}

[1] IAEA, "High Temperature Gas Cooled Reactor Fuels and Materials," IAEA Tecdoc 1645, pp. 1-182, 2010.

[2] X. W. Zhou, Y. P. Tang, Z. M. Lu, J. Zhang, and B. Liu, "Nuclear graphite for high temperature gas-cooled reactors," Xinxing Tan Cailiao/New Carbon Mater., vol. 32, no. 3, pp. 193204, 2017.
[3] T. Setiadipura, S. Bakhri, G. R. Sunaryo, and D. S. Wisnusubroto, "Cooling passive safety features of Reaktor Daya Eksperimental," AIP Conf. Proc., vol. 1984, 2018.

[4] T. Setiadipura, D. Irwanto, Zuhair, "Preliminary Neutronic Design of High Burnup OTTO Cycle Pebble Bed Reactor," Atom Indonesia, Vol. 41 No. 1, pp. 7-15, 2015.

[5] C. Tang, Y. Tang, J. Zhu, Y. Zou, J. Li, and $\mathrm{X}$. Ni, "Design and manufacture of the fuel element for the $10 \mathrm{MW}$ high temperature gas-cooled reactor," Nucl. Eng. Des., vol. 218, no. 1-3, pp. 91-102, 2002.

[6] H. Zhao, T. Liang, J. Zhang, J. He, Y. Zou, and C. Tang, "Manufacture and characteristics of spherical fuel elements for the HTR-10," Nucl. Eng. Des., vol. 236, no. 5-6, pp. 643-647, 2006.

[7] IAEA, "Advances in High Temperature Gas Cooled Reactor Fuel Technology," in IAEA TECDOC CD 1674, 2012, pp. 1-690.

[8] S. Yeo, J. Yun, S. Kim, M. S. Cho, and Y. W. Lee, "Fabrication methods and anisotropic properties of graphite matrix compacts for use in HTGR," J. Nucl. Mater., vol. 499, pp. 383-393, 2018.

[9] Sukandarrumidi, "Bahan Galian Industri," Gadjah Mada University Press, pp. 223-24, 2016.

[10] R. Marza, W. Setiyawan, and H. Rodiana, "Keprospekan Mineral Grafit di Pulau Kalimantan dan Pulau sulawesi," Pros. Has. Kegiat. Pus. Sumber Daya Miner. Batubara dan Panas Bumi Tahun Anggar. 2017, vol. Buku 2 : B, pp. 219-229, 2018.

[11] F. F. Florena et al., "Floatability study of graphite ore from southeast Sulawesi (Indonesia)," AIP Conf. Proc., vol. 1712, 2016.

[12] I. M. Joni et.al., "Synthesis and dispersion of nanoparticles, and 
Indonesian graphite processing," AIP Conf. Proc., vol. 1554, pp. 20-26, 2013.

[13] C. Panatarani, A. O. Maulana, A. Rianto, and I. M. Joni, "Preparation of graphite oxide by sodium cholate intercalation and sonication from Indonesian natural graphite," AIP Conf. Proc., vol. 1712, 2016.

[14] D. Mustika, et.al. "Purification of Indonesian Natural Graphite by Acid Leaching Method as Nuclear Fuel Matrix : Physical Characterization". International Journal of Chemistry, Vol. 11, No. 1, 2019.

[15] K. Zaghib, et al. "Purification Process of Natural Graphite as Anode for LiIon Batteries: Chemical versus Thermal." Journal of Power Sources, vol. 119-121, 2003, pp. 8-15.

[16] H. Zhao, et al. "Purification and Carbon-Film-Coating of Natural Graphite as Anode Materials for Li-lon Batteries." Electrochimica Acta, vol. 52, no. 19, pp. 6006-6011, 2007.

[17] K. Shen, et al., "Advantages of Natural Microcrystalline Graphite Filler Over Petroleum Coke in Isotropic Graphite Preparation," Carbon, vol. 90, pp 197206, 2015.

[18] W. Xie, et al. "Fixed Carbon Content and Reaction Mechanism of Natural
Microcrystalline Graphite Purified by Hydrochloric Acid and Sodium Fluoride." International Journal of Mineral Processing, vol. 155, pp. 4554, , 2016.

[19] L. Y. Feng, Z. S. Fu, A. Yun. "Selectivity Heating Effect of Microwave on Purifying of Natural Graphite." Applied Mechanics and Materials, vol. 174-177, pp. 810-15, 2012.

[20] Y. R. Shin et. al. "The Oxidation Mechanism of Highly Ordered Pyrolytic Graphite in a Nitric Acid/Sulfuric Acid." Carbon, vol. 52, pp 493-498, 2013.

[21] ASTM, "Standard Test Method for Ash in a Graphite Sample C 561". ASTM International. 2010

[22] ASTM, "Standard Practice for Determining Equivalent Boron Contents of Nuclear materials C 1233". ASTM International. 2015

[23] Leco, "CS 744 Carbon and Sulphur Analyzer Instruction Manual Leco, version 1.9.x, Part Number 200-749, LECO Corporation", Januari, 2014.

[24] A. Fisli, et. al. "Determination of Elements in Acid Leaching of Graphite Using Instrumental Neutron Activation Analysis". International Journal of Chemistry, Vol. 12, No. 1, 2020. 
